\title{
Human Saliva Acting as an Allergen
}

\section{William Frankland $\mathrm{A}^{1}$ and Jill A Warner ${ }^{2 *}$}

${ }^{1} E$ meritus Consultant, St. Mary's Hospital, London and Guy's Hospital London, London, UK ${ }^{2}$ Imperial College London, Medical School Building, Norfolk Place, London, UK

\section{Background}

In animal allergic subjects saliva may be an important allergen. In laboratory animal workers animal allergy is usually due to inhalant allergens causing allergic rhinoconjunctivitis and asthma but rodent bite anaphylaxis may occur. Immunotherapy has been used with complete resolution of rhinitic symptoms after working with mice, using a stock extract of Musmusculus [1]. Anaphylaxis has also been reported to rat bite [2].

Allergy to dog (Canisfamiliaris) is a worldwide problem. Commercial extracts of dog for allergy testing both in vitro and in vivo are obtained from dog dander. However patients who have clearly dog related symptoms may give negative diagnostic results. A recent article has shown that dog saliva is an important source of dog allergens with four new allergens that are not normally present in the current dog extracts. Also the IgE binding proteins in saliva from different breeds of dog vary [3]. Patients often tell us that some breeds of dogs cause more allergic symptoms than others. It was shown that dog saliva has a greater potential than dander as an allergen source but only one fifth of patients with symptoms to dog but lacking IgE antibodies to dog dander were IgE positive to saliva. What was not tested was dog urine which is known to contain a prostatic kallikrein, a major dog allergen [4].

\section{Case Report}

We report a case of a 25 year old female who reacted with immediate local urticaria of the face and swelling of the eyes when her partner kissed her. Her past history is interesting because her asthma started 5 years previously after a rather traumatic divorce. The asthma started after she commenced living with the partner who she hoped to marry -she and her partner were heavy smokers. She had a manic depressive personality which she thought was made worse by oral steroids which, besides all her other symptomatic treatment for her severe asthma, had to be used on many occasions during the last five years. She has been an inpatient in hospital to treat her asthma but also been in hospital under the psychiatrists for acute depression which the patient stated followed a crisis towards the end of a course of oral steroids.

Six months before she was first seen, 2 cats had been introduced to her environment. She was cat allergic but she did not complain of conjunctivitis or rhinitis in the presence of cats, even so because of the severe asthma she was advised that the cats must be removed. Skin prick tests were positive to cat but not to dust mite or grass or tree pollens. She was not allergic to any foods including fresh fruits.

\section{Skin testing to saliva}

Her partner produced $30 \mathrm{ml}$ of his saliva that was filtered, dialysed and freeze dried to make up the material for skin prick testing using Coca's glycerol. The results of the skin tests in the patient are shown in Table 1.

Using the $10 \mathrm{mg}$ strength of saliva, skin tests in atopic and nonatopic volunteers were uniformly negative. What was surprising was that no flare was produced in the patient's positive saliva test. This may occur in some drug-allergic patients who produce a positive wheal but no flare (personal communication Dr Rita Mirakian).

\section{Treatment of Saliva Allergy}

One possibility from the patient's medical history suggests she might also be allergic to her partner's skin scales and that if these were inhalant allergens, might be the cause of her severe asthma. All male staff in the allergy department who used an electric razor was asked to collect their shaving material for 3 months, as was the patient's partner. It was hoped to skin test using individual solutions of skin scales from the partner and staff to see if she might react possibly only to her partner's skin scales. It was noted that the shaving skin was grossly contaminated with Staphylococcus. It has been shown that in a GA ${ }^{2} L E N$ study that in 2908 subjects specific IgE to Staphylococcus aureus enterotoxins (SE-IgE) was positive in $29.3 \%$-the SE-IgE was more common in smokers [5]. Staphylococcus enterotoxin-specific IgE is associated with asthma in the general population [6]. The patient said that she was very willing to try sub-cutaneous therapy using her partner's saliva after she was told that in the one patient out of seven who had anaphylaxis caused by exposure to her husband's semen successful immunotherapy with his semen had produced a complete cure which was long lasting (10 years). The patient said that she had no local or general symptoms immediately after intercourse except on her lips and face. Unfortunately the patient failed to keep a follow-up appointment and it was learned that she had subsequently taken an overdose which proved fatal.

\section{Discussion}

Saliva from animals causes local urticarial and also inhalant allergic symptoms. Recent studies have shown that human CD4+ T cell responses are similar to both the major dog allergen Can $\mathrm{f} 1$ and its human homologue tear lipocalin [7]. Bites from rodents can also cause anaphylaxis.

\begin{tabular}{|l|c|c|}
\hline & Wheal & Flare \\
\hline Negative control & $0 \mathrm{~mm}$ & $0 \mathrm{~mm}$ \\
\hline Histamine control & $7 \mathrm{~mm}$ & $17 \mathrm{~mm}$ \\
\hline Saliva $\mathbf{1 0} \mathbf{~ m g}$ & $8 \mathrm{~mm}$ & $0 \mathrm{~mm}$ \\
\hline Saliva $\mathbf{1} \mathbf{~ m g}$ & $3 \mathrm{~mm}$ & $0 \mathrm{~mm}$ \\
\hline
\end{tabular}

Table 1: The results of skin prick tests in the patient tested with her partner's saliva extracts.

*Corresponding author: Jill A Warner, Reader in Allergy and Immunology, Imperia College London, St. Mary's Campus, Room 250, Medical School Building, Norfolk Place, London W2 1PG, UK, Tel: 02075943697; E-mail: jill.warner@imperial.ac.uk

Received May 05, 2014; Accepted September 29, 2014; Published October 06 2014

Citation: William Frankland A, Warner JA (2014) Human Saliva Acting as an Allergen. J Allergy Ther 5: 193. doi:10.4172/2155-6121.1000193

Copyright: (C) 2014 William Frankland A, et al. This is an open-access article distributed under the terms of the Creative Commons Attribution License, which permits unrestricted use, distribution, and reproduction in any medium, provided the original author and source are credited. 
A patient is described who clinically and by skin prick testing had local allergic symptoms from the partner's saliva. From the time that she lived with the partner she also suffered severe asthma. Unfortunately it was impossible to test for the possibility that her asthma might be due to his skin scales as the patient subsequently took an overdose that proved fatal. It would have been very interesting to perform analysis on both the saliva and skin scales of the partner to identify the specific allergen as publications subsequent to the investigation of this case have suggested that lipocalin allergens may be important $[8,9]$. Positive skin prick tests were obtained from his saliva in this patient, but the saliva extract did not cause a reaction in normal, non-allergic subjects. There is also the question of whether the cigarette smoking might have enhanced the allergenic activity of the salivary proteins [10] and whether there was any periodontal disease in the partner which might have influenced histamine levels in the partner's saliva in combination with the cigarette smoking [11]. The inability to follow this case further is disappointing, but the case does raise some interesting future directions of study.

\section{References}

1. Bunyavanich S, Donovan MA, Sherry JM, Diamond DV (2013) Immunotherapy for mouse bite anaphylaxis and allergy. Ann Allergy Asthma Immunol 111: 223-224.

2. Hesford JD, Platts-Mills TA, Edlich RF (1995) Anaphylaxis after laboratory rat bite: an occupational hazard. J Emerg Med 13: 765-768.
3. Polovic N, Waden K, Binnmyr J, Hamsten C, Gronneberg R, et al. (2013) Dog saliva-an important source of dog allergens. Allergy 68: 585-592

4. Mattsson L, Lundgren T, Everberg H, Larsson H, Lidholm J (2009) Prostatic kallikrein: a new major dog allergen. J Allergy Clin Immunol 123: 362-368.

5. Tomassen P, Jarvis D, Newson R, Van Ree R, Forsberg B, et al. (2013) Staphylococcus aureus enterotoxin-specific $\lg E$ is associated with asthma in the general population: a GA(2)LEN study. Allergy 68: 1289-1297.

6. Song WJ, Chang YS, Lim MK, Yun EH, Kim SH, et al. (2013) Staphylococcal enterotoxin sensitization in a community-based population: a potential role in adult-onset asthma. Clinical and Experimental Allergy 44: 553-562

7. Liukko AL, Kinnunen TT, Rytkönen-Nissinen MA, Kailaanmäki AH, Randell JT et al. (2014) Human CD4+ T cell responses to the dog major allergen Can $f$ and its human homologue tear lipocalin resemble each other. PLoS One 9: e98461.

8. Virtanen T, Kinnunen T, Rytkönen-Nissinen M (2012) Mammalian lipocalin allergens--insights into their enigmatic allergenicity. Clin Exp Allergy 42: 494504

9. Ghafouri B, Tagesson C, Lindahl M (2003) Mapping of proteins in human saliva using two-dimensional gel electrophoresis and peptide mass fingerprinting. Proteomics 3: 1003-1015.

10. Jessie K, Pang WW, Haji Z, Rahim A, Hashim OH (2010) Proteomic analysis of whole human saliva detects enhanced expression of interleukin-1 receptor antagonist, thioredoxin and lipocalin-1 in cigarette smokers compared to nonsmokers. Int J Mol Sci 11: 4488-4505

11. Bertl K, Haririan H, Laky M, Matejka M, Andrukhov O, et al. (2012) Smoking influences salivary histamine levels in periodontal disease. Oral Dis 18: 410416. 